effect is produced on the parthenogenetic females. D. D. WhitNeY

WESLEYAN UNIVERSITY, Middletown, Conn., August 15, 1910

\section{A REPORT ON THE FRESH-WATER PROTOZOA OF TAHITI $^{1}$}

THE following brief report is a result of some work done upon the protozoa of Tahiti during the months of July and August, 1908.

An oceanic island is always an interesting field for the investigation of the higher forms of animals, because of its faunal peculiarities or deficiencies, but a valid question arises, namely, may we expect these same peculiarities or deficiencies to exist with respect to animals of the lowest rank?

So far as the writer has been able to determine, no list of fresh-water protozoa of a mid-ocean island has previously been reported.

Tahiti, the largest of the Society group, is situated $17 \frac{1}{2}^{\circ}$ south latitude, $1491^{\circ}$ west longitude. It is a high island of over 400 square miles, of volcanic origin, more or less densely covered with a tropical vegetation. Mountains of the interior reach a height of nearly 8,000 feet, and numerous streams of fyesh water flow down the valleys across the narrow plain to the sea.

During the winter months of July and August, in Tahiti, the small streams are in a low condition, it being the dry season, and many of them are choked with plants of low orders, which would apparently be a fit condition for the presence of a rich microscopic fauna.

During the brief time allotted to the study of the protozoa, collections were made in many places from the waters of this border zone a few yards from the sea and from its level to a few feet above.

In all, forty-four species were observed and studied with considerable care. Of these, thirty-six were positively identified, and eight referred to their proper genera, but the species undetermined.

1 Read before the Central Branch of the American Society of Zoologists at Iowa City, April, 1910.
Of the thirty-six species identified, nine were of the class Sarcodina, six of the class Mastigophora, and twenty-one of the elass Infusoria. Of the undetermined species, two were rhizopods and six ciliates.

All of the thirty-six species studied in Tahiti are more or less common in the waters of this state; twenty of them have been reported from Boulder, Col., by Cockerell; and nearly all of them from Connecticut by Conn.

Penard, in the American Naturalist for December, 1891, lists thirty-six species of rhizopods found in the Rocky Mountains near Caribou, Col., at a height of 10,000 feet, and thirteen species at 12,000 feet. Of the thirtysix species listed by Penard at an elevation of 10,000 feet, six species were found in tropical Tahiti within a few feet of the level of the sea. Of the thirteen species listed by Penard found at an elevation of 12,000 feet, one Difflugia pyriformis, is a rather common rhizopod in Tahiti at sea-level.

Penard calls attention to the fact that the rhizopoda of higher altitudes are those with lobe-like pseudopodia, the forms with raylike pseudopodia being absent. It may be added that the predominating rhizopods of the sea-level are also of the lobose type, and a majority are protected by shells. Only one species of rhizopoda with ray-like pseudopodia was found in Tabiti.

Taking as a basis the list of protozoa reported by Stokes in 1888, the list reported by Conn in 1905, and the list of the writer in 1906, it is quite safe to say that the relative proportion of the protezoa for the United States of the three classes (sporozoa not included), is approximately as follows: Sarcodina, 15 per cent.; Mastigophora, 25 per cent., and Infusoria, 60 per cent.

Taking forty-four species of Tahiti as a basis, the proportion is as follows: Sarcodina, 25 per cent.; Mastigophora, 14 per cent.; Infusoria, 61 per cent.

It would seem from these observations that the proportion of infusoria reported in the oceanic island holds true to that of the United States, a variance appearing in the case of the other groups.

Among the pseudopodia-bearing forms, $\mathrm{Ar}$ - 
cella vulgaris and Centropyxis aculeata, shell-bearing rhizopods, were most abundant. These are among the more common species in the United States. Only one species with ray-like pseudopodia was observed, a member of the genus Raphydiophrys, probably a new form.

The scarcity of Mastigophora was especially marked. In material where certain common forms are usually found in swarms there were none. The Euglenidæ were few in species and in number of individuals. Only one form of flagellate was at all common, Chilomonas paramecium, which may be found almost everywhere in stagnant water.

The class Infusoria was well represented except in a few particular groups.

The Vorticellidæ, common forms with us, were represented in the collections by only four species, rarely seen and only one of which could be identified as a North American species. None of the beautiful colonial examples of Epistylis or Carchesium were found.

Stentor was not discovered, even in the old infusions, after fermentation had taken place.

No members of the subclass Suctoria were obtained. This failure, however, does not indicate that none existed, as these forms are by no means abundant in any locality.

The list as reported is not a large one, but nevertheless is a representative one, comprising 21 families and 34 genera.

In June, 1908, the writer did enough work on the protozoa of southern California to conclude that the one-celled animals of that region are identical with those of the central portion of the United States, and the species here are, for the most part, reported from eastern United States by Stokes, Conn, Palmer and others.

A species of Colpoda, common in this state, was, during the summer of 1906 , the predominating species in infusions of the leaves of the shrub on Loggerhead Key, Dry Tortugas.

It is well known that environment may have a direct morphological and physiological influence upon the protoplasm of the unicellular animal, and, no doubt, external factors are instrumental in the production of the numerous variations of certain protozoa, yet the significant fact is that there is a constancy of species and that a given species may flourish under very diverse habitat conditions.

All of the evidence indicates that very many species of protozoa are widely distributed throughout the United States and many of these same species are common forms in oceanic islands separated from our shores by several thousands of miles of sea.

It is safe to conclude, I believe, that on every land surface of the earth, where moisture abounds, within wide range of latitude and altitude, we may expect to find, not only genera, but species of protozoa identical with those of this immediate vicinity.

Appended is a list of the species of protozoa reported from Tahiti.

Sarcodina:

Amoeba proteus

Amoeba radiosa

Dinamoba sp.

Diffugia pyriformis

Arcella vulgaris

Arcella discoides

Centropyxis aculeata

Cochliopodium bilimbosum

Euglypha alveolata

Trinema enchelys

Raphidiophrys sp.

Mastigophora:

Euglena viridis

Euglena acus

Astasia trichophora

Entosiphon sulcatus

Notosolenus opocamptus

Chilomonas paramecium

Infusoria :

Coleps hirtus

Prorodon edentatus

Mesodinium sp.

Lacrymaria truncata

Lionotus fasciola

Loxodes rostrum

Chilodon cucullulus

Loxocephalus granulosum

Urocentrum tubro

Microthorax sulcatus

Cinetochilum margaritaceum

Paramecium caudatum

Paramecium trichium 


\section{Cyclidium glaucoma \\ Metopus sigmoides \\ Uroleptus agilis \\ Oxytricha fallax \\ Stylonychia sp. \\ Stylonychia sp. \\ Euplotes patella \\ Euplotes charon \\ Aspidisca costata \\ Vorticella citrina \\ Vorticella sp. \\ Vorticella sp. \\ Vorticella sp.}

\section{WAshburn CoLLege,} TOPERA, KaN.

\section{H. Edmondson}

THE FOOD REQUIREMENTS OF GROWING OHILDREN

A comparatively large number of investigations have been made with the view of determining the amounts of nutrients required in average normal adult life and, although they can not be considered as final, some rather definite conclusions have been drawn. The data available for children are much more limited. It is recognized that a higher allow ance should be given them to provide for their greater degree of tissue building, greate loss through radiation and evaporation from the relatively larger body surface, and, possibly, for their comparatively greater activity, Certain standards have been proposed for children, sometimes from limited observations, sometimes from theoretical considerations. Thus the following percentages of adult requirements have been suggested ${ }^{2}$ for children.

\begin{tabular}{r|c|c|c|c|c}
\hline Age, Years & F oliy & Atwater & $\begin{array}{c}\text { U.S. Bureau } \\
\text { of Labor }\end{array}$ & $\begin{array}{c}\text { Rown- } \\
\text { tree }\end{array}$ & Engel \\
\hline 7 to 10 & -- & 50 to 60 & 75 & 50 & 57 \\
11 to 14 & 60 & 70 to 80 & 90 & 60 & 70 \\
\hline
\end{tabular}

The U. S. Department of Agriculture ${ }^{3}$ has

${ }^{1}$ From the Chemical Laboratory of the University of Iowa.

${ }^{2}$ Quoted by Chapin, "The Standard of Living among Workingmen's Families," Charities Publication Committee, $\mathrm{N}$ ew York, p. 15.

${ }^{3}$ U. S. Department of Agriculture Yearbook, 1907, p. 365 . adopted standards for the nutrients for chil dren at different ages, assuming, among others, as the proper food for a child of from 6 to 9 years 50 per cent. of the food of a man, that is, 53 grams of protein and 1,750 calories of energy, and for a boy of 12 years 70 per cent. of the food of a man, which would be 74 grams of protein and 2,450 calories of energy.

Knight, Pratt and Langworthy ${ }^{4}$ have recently issued the results of dietary studies in children's homes in Philadelphia and Baltimore and have there reviewed the literature: In Philadelphia, 80 children whose ages were from less than 6 up to 18 years, averaging about 10 years, consumed per day an average of 67.6 grams of protein, 57.9 grams of fats and 270.1 grams of carbohydrates with a total energy value of 1,867 calories. The duration of the test was seven days. In Baltimore, 115 . boys and girls aged from 4 to 17 years, with an average age of 12 years and weighing from 31 to 109.5 pounds, consumed an average of 65 grams of protein, and other food to a total of 1,798 calories of energy. In another home in Baltimore for colored children 25 boys, from 3 to 13 years of age, and weighing from 37 to 85 pounds each, consumed daily 50 grams of protein and the fuel value of the food was 1,677 calories. The average of the ages was 9 years. In each of the Baltimore tests the duration was 21 meals. In one the children had an abnormally low body weight and in the other they were "none too well nourished."

It is evident, in tests like these last, where there is so great a variation in age and body weight that definiteness is wanting: in the results, and that they can stand for nothing more than very general averages. Considering that there is no general agreement as to adult requirements, standards stated as fractions of the amounts necessary for adults are obviously not exact. The value of more definite information as to children's needs is evident.

The daily dietaries of two boys were deter-

- Bulletin 223, Office of Experiment Stations, Washington. See also Experiment Station Bulletins 21 and 45 for literature. 